\title{
41
}

\section{LANDFILL MINING: \\ Space Saving, Material Recovery and Energy Use}

\author{
William Hogland \\ University College of Kalmar, Lund University \\ Marcia Marques Gomes \\ Lund University Rio de Janeiro State University - UERJ, \\ Lars Thörneby \\ Lund University \\ Sweden
}

\section{INTRODUCTION}

Landfill mining (LFM) is the excavation and treatment of waste from an active or closed landfill for one or more of the following purposes: conservation of landfill space, reduction in landfill area, elimination of a potential contamination source, mitigation of an existing contamination source, energy recovery from excavated waste, reuse of recovered materials, reduction in waste management system costs, and site redevelopment.

LFM involves the excavation; screening and separation of material from older (generally unlined) landfills into various components including soil, recyclable materials, hazardous materials and reject waste.

Landfill mining is first mentioned in the literature in 1958 as a method used in Israel, to obtain soil replacement material. It was later employed in the USA to obtain fuel for incineration and energy recovery. During the period 1987 to 1993, six landfills were excavated and material recovered, in the USA (TWRF, 1995). In 1992, two commercial-scale applications of landfill mining were in operation and others have since been initiated on pilot or demonstration scales. 
Projects have been conducted by both public and private sponsors (Spencers, 1990). Surveys have been carried out in order to establish whether it is possible to recover the whole landfill or parts of the landfill instead of final capping and control and maintenance for up to 30 years, according to the demand in some Federal regulations. Nelson (1994) mentioned 15 projects in landfill mining running in the USA at that time. Demonstration projects have been initiated by the New York State Energy Research and Development Authority and the United States Environmental Protection Agency (Salemi, 1992), and a Landfill Reclamation Manual was produced in 1995 (Salerni, 1995).

The first experience of LFM in Europe was gained in Germany, at the Burghof landfill site, where a demonstration plant has been operating since 1993 (Rettemberger and Göschl, 1994; Rettemberger, 1995). A full-scale landfill mining plant is now under construction. Presently, a landfill mining project has been carried out at the Schöneiche landfill, one of the largest European sites, where the domestic waste from the westem part of Berlin and the industrial and commercial waste from the former Eastem Germany have been dumped for 15 years (Obermeier and Saure, 1995). Other landfill sites are Dresden, Baßlitz, Döbeln-Hohenlauft which are located in the new federal states. The main purpose of the excavations has been environmental remediation and the construction of new landfills according to modem technology (Bilitewski et al., 1995).

The first study of landfill mining in Italy was performed at an old landfill site in Sardinia, in 1994 (Cossu et al., 1995). The study was aimed at obtaining all the design parameters, such as landfill characteristics, quality of old waste, setting-up options for sorting and treatment plant and all measures to be undertaken in situ during the excavation phase. Projects have also started in Spain and Austria.

In Sweden approximately $50 \%$ of MSW and $95 \%$ of industrial waste has been landfilled during the last 3-4 decades. Today, there are 6,000 old landfills (dumps) about 200 of wheich present high environmental risks, requiring intervention. In former times, numerous landfills were used in each community, but today efforts are made to reduce these to a few well-kept sites. During the summer of 1994 a 10-year-old part of the Filboma landfill (Waste Company of Northwest Scania, NSR) was excavated as a pilot test in a research project (Hogland et al., 1995). In 1996, an intemational workshop on landfill mining was organised in Sweden in order to bring together researchers and practitioners from different count ries (Hogland, 1996).

In the early 1970s, the first archaeological research into modem refuse, "The Garbage Project", was started at Tucson University-USA (Rathje \& Murphy, 1992). The main objective was to sort rubbish as if it came from a prehistoric excavation, thus leaming how to classify and describe the material. A project called "Archaeology and Modern Waste" was started in 1997 in Sweden. Archaeological research is traditionally associated with the excavation and analysis of prehistoric remains. Waste is of great importance in archaeology research. The documentation of waste and the interpretation of findings are probably the most 
important factor in gaining information about prehistoric society. The archeological approach and methodology will be adapted for this project.

\section{OBJECTIVES}

The objectives of a landfill mining project may be any of all the following:

- Reduction in the landfill area, finishing or closure of the landfill

- Total decontamination

- Material recovery and/or construction of a new landfill

- Upgrading and installation of a bottom liner

- Volume reduction /continuation of operation on existing site and

- Material recovery and reuse, such as:

- soil as cover material

- material for energy recovery

other materials, such as wood, for production of wood chips, stones, bricks and mortar for road construction, concrete for crushing into coarse material for road construction and metals such as iron, copper and aluminum for recovery.

\section{PRELIMINARY SURVEY}

Before starting up a landfill mining project, a preliminary investigation including the following steps must be carried out:

- definition of the site characteristics where unknown (topography, morphology, volume, thickness of the waste pile, operating history),

- identification and estimation of the extent of a possible contamination zone,

- collection of information on the quality, extent and composition of dumped waste; to assess potential risks during LFM (estimation of the presence of gas, stability of waste mass, soil-to-waste ratio, chemical analysis of recovered soils and below-waste soil),

- preliminary evaluation of the technical and economical feasibility, regulatory guidelines and project logistics.

Methodologies for preliminary studies have been developed in different countries (Cossu et al., 1990, 1995; Laudadio, 1995; Salemi, 1995). At this stage, a plan is developed including a list of equipment, digging tests, material handling procedures, labour, amount and kind of analytical testing and data collection requirements. Furthermore, feasibility studies and a contingency plan drawn up. 


\section{EXCAVATION AND EQUIPMENT}

After excavation, the waste material can be processed using a variety of equipment such as: screens, density separators, magnetic separators, and conveyors. The choice of equipment depends on the project goals, in particular regarding the final deposition of the soil and waste. The landfilled material can be removed using an excavator or a front-end loader. The physical characteristics of the waste material and the ultimate method of disposition determine how it should be handled and also what should be done with the soil fraction (Salerni, 1995).

Excavator - Traditional track excavators (Photograph 1) used in construction work are suitable. Clearance to dig, swing and cast material onto the screen (Photograph 2) must be considered.

Loaders - Bucket loaders are used to load screens with material retrieved by the excavator and to move screened material around the site. The size of the bucket must be appropriate.

Material processing - The materials can be processed in different ways after excavation depending on the aims of the operation. Screening can be carried out with; flat/mesh screens, finger screens or trammel screens.

Additional processing may include:

1) manual separation,

2) magnetic separation,

3) air classification/de-stoning,

4) aluminium removal,

5) optical sorting and

6) size reduction.

When selecting additional processing equipment the reject quality, soil quality, moisture content, production rate, mobility of the equipment, reliability, availability and cost should be considered. In Figure 1, a scheme for complex processing is shown.

The different streams may include a not processable soil fraction, a combustible fraction and in some cases, by a density classifier, a light fraction containing plastics and a heavy fraction containing non-ferrous metals such as aluminium.

The soil fraction is usually used on-site directly or stockpiled. Secondary material and the fuel fraction can be transported off-site for further processing. Noncombustibles and remaining residues are landfilled again (Savage and Diaz, 1994). 


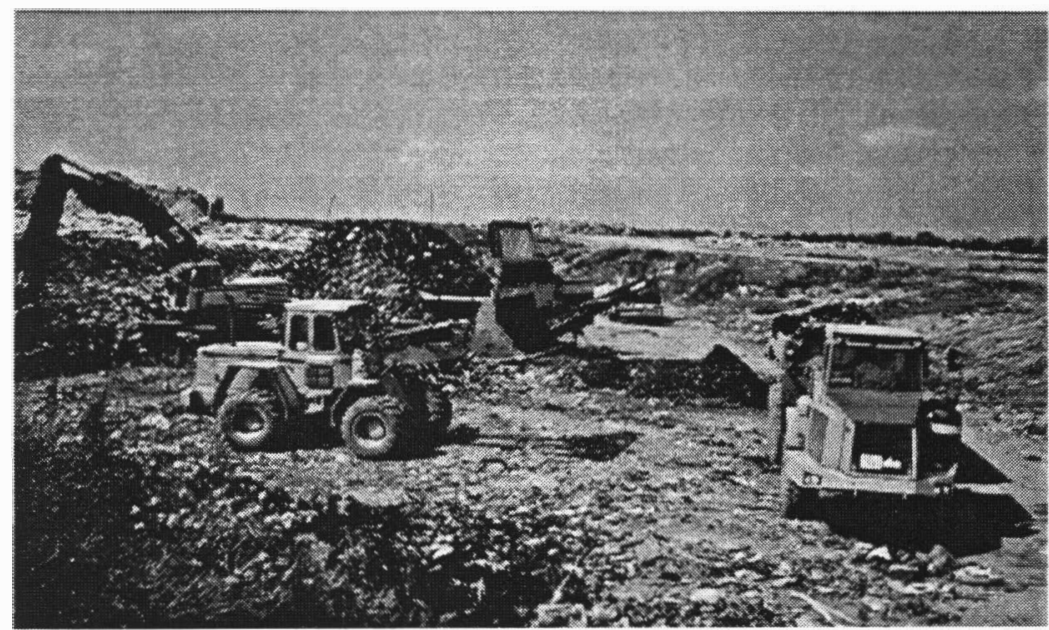

Photograph 1. Excavator, front loader, dumper and drum screen used during excavation.

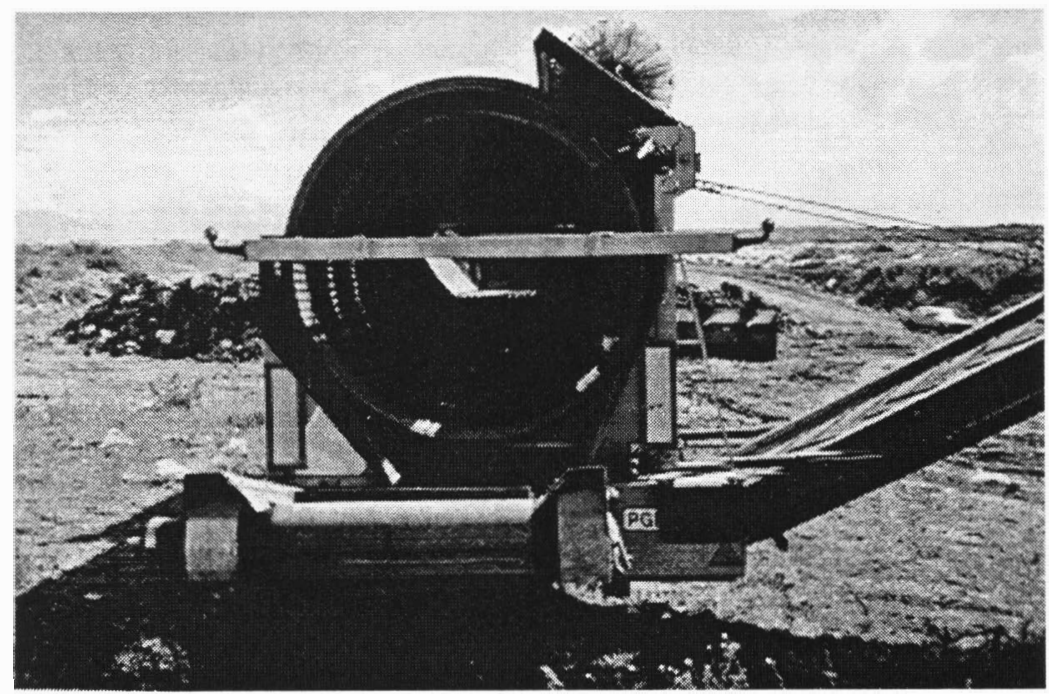

Photograph 2. Mobile drum screen. 
Special procedures should be developed for treating hazardous waste found during mining activities. Asbestos can be landfilled again, but other types of hazardous waste must be removed for destruction or safe storage.

Screens - Several types exist on the market. Specification, production rates and appropriate sizes should be known before selection.

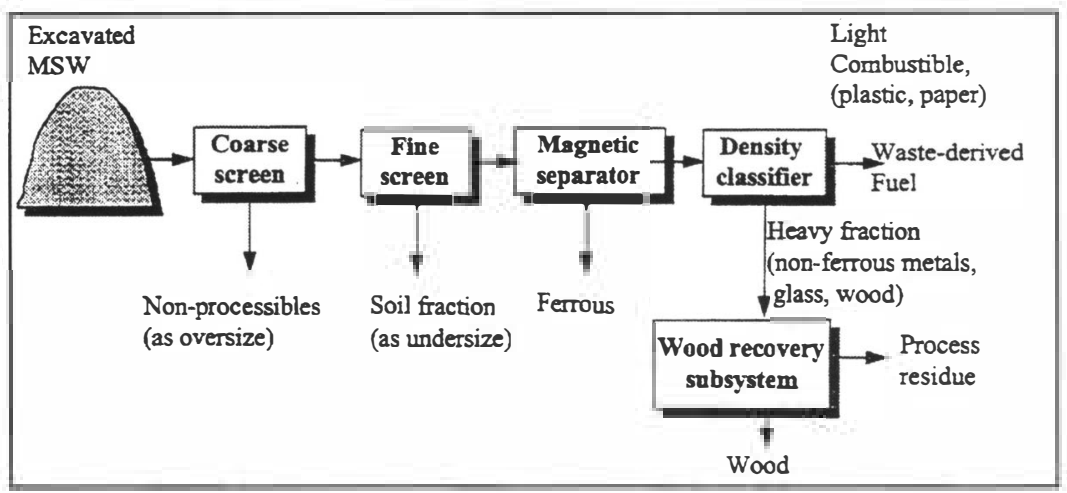

Fig. 1: Process scheme for a LFM plant (after Savage and Diaz, 1994).

Ferrous metal removal - Magnetic head pulleys on conveyors are not effective. Suspended magnets work better but they are more complicated to operate.

Removal of recyclable material - Bulk metals, such as white goods, are removed directly by the excavator prior to screening. Recyclable material, such as paper, glass and plastic, must be separated manually.

Shredding/volume reduction - Shredding of the waste after screening reduces the volume. The benefits of shredding must be weighed against the increased cost.

\section{COMPOSITION OF EXCAVATED WASTE}

The greatest variable in reclaimed landfills is the amount of recovered soil/compost mix passing through the screens. This varies with the amount of cover soil originally applied as cover material, the degree of degradation of the waste, and the gauge of the screen used. The recovery percentage depends upon the physical and chemical properties and the effectiveness of the mining technology employed. Figures 2 and 3 show the variation in waste composition of the screened waste fraction from several landfill reclamation projects.

After screening, the composition of the recovered waste will vary with the type of landfill, the local waste stream (specially the content of commercial and industrial waste), the tipping practices employed at the landfill, and the extent of decomposition. Rates of recovery could be: 85 to $95 \%$ for soil, 70 to $90 \%$ for ferrous materials, and 50 to $75 \%$ for plastics. The potential purity may be: 90 to $95 \%$ for 
soil, 80 to $95 \%$ for ferrous materials, and 70 to $90 \%$ for plastics (Savage et al., 1993).

The degree of waste decomposition varies at landfill reclamation sites, and is affected by factors such as the type of waste, depth of waste, type and amount of cover soil applied, compaction efforts, local climate and age.

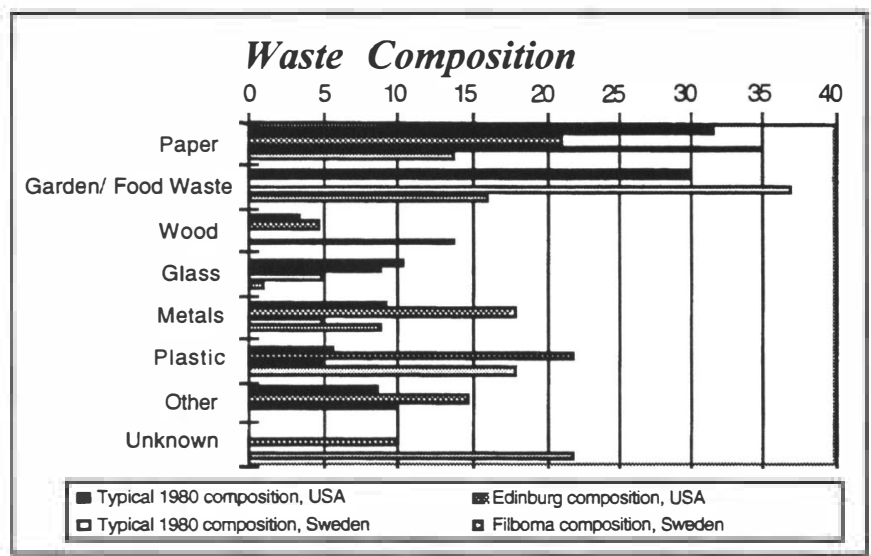

Fig. 2: Waste composition in USA and in Sweden in 1980 vs Edinburg landfill residuals during 1977-1979 and Filborna landfill residuals in 1995. Source: Frankling Associates 1990 (Visalli et al., 1992); Filborna landfill in Sweden (Hogland et al., 1995).

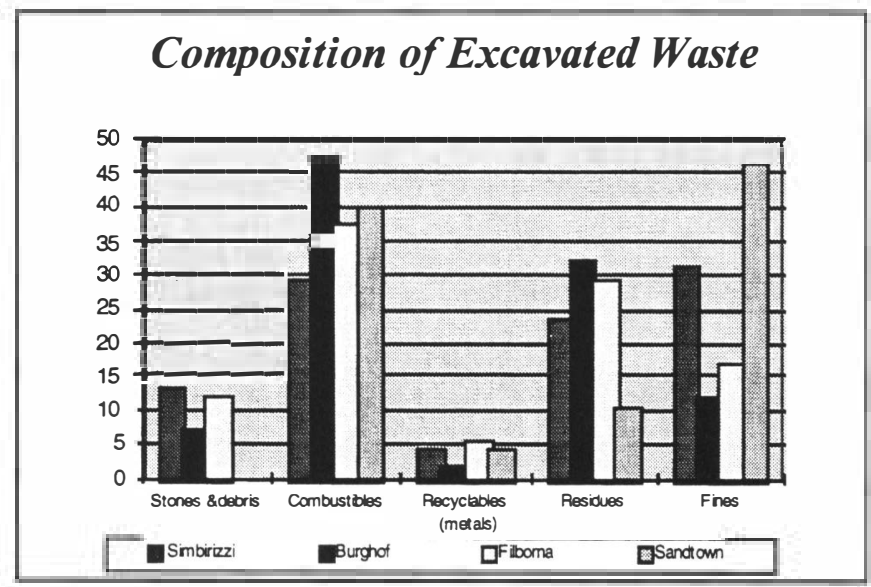

Fig. 3: Composition of excavated waste in four different European LFM projects (Cossu et al., 1995; Hogland et al., 1995, Rettenberger and Göschl, 1994). 


\section{TEST RESULTS FROM SWEDEN}

About $1300 \mathrm{~m} 3$ of waste were excavated to a depth of $8.5 \mathrm{~m}$ in a 10-year-old part of the landfill in Filboma, Sweden (Hogland et al. 1995). The total amount of waste screened was 275 tonnes. The coarse fraction ( $340 \mathrm{~mm}$ ) was $45 \%$ by weight of the total amount of waste and the fine fraction was 55\% 0-5 m below the surface and $25 \%$ and $75 \% 5-8 \mathrm{~m}$ below surface. The characteristics of the waste on different levels are shown in Table 1.

Table 1. Characteristics of the waste 0-5 $\mathrm{m}$ and 5-8 $\mathrm{m}$ below the surface.

\begin{tabular}{|c|c|c|c|c|c|c|c|c|c|c|c|c|}
\hline \multirow[b]{2}{*}{ Level } & \multirow[b]{2}{*}{$\mathbf{p H}$} & \multirow[b]{2}{*}{$\underset{{ }^{\circ} \mathrm{C}}{\text { Temp }}$} & \multirow[b]{2}{*}{$\mathbf{C H}_{4}$} & \multirow[b]{2}{*}{$\mathrm{CO}_{2}$} & \multicolumn{4}{|c|}{$\begin{array}{l}\text { Coarse fraction: amount by volu- } \\
\text { me, amount by weight. densty and } \\
\text { moisture }\end{array}$} & \multicolumn{4}{|c|}{$\begin{array}{l}\text { Fine fraction: arnount by wolume, } \\
\text { a mount by weight, density and } \\
\text { moisture }\end{array}$} \\
\hline & & & & & $\begin{array}{l}\text { by } \\
\text { Vol. }\end{array}$ & $\begin{array}{l}\text { by } \\
\text { wt }\end{array}$ & $\begin{array}{c}\text { density } \\
t / m^{3}\end{array}$ & $\begin{array}{l}\text { Moist. } \\
\text { by wt }\end{array}$ & $\begin{array}{l}\text { by } \\
\text { vol. }\end{array}$ & by wt & $\begin{array}{l}\text { dens. } \\
t / m^{3}\end{array}$ & $\begin{array}{l}\text { moist. } \\
\text { By wt }\end{array}$ \\
\hline $0-5 \mathrm{~m}$ & $4-5$ & 17 & 4 & $r$ & $35 \%$ & $45 \%$ & 0.5 & $38 \%$ & $65 \%$ & $55 \%$ & 0.4 & $30 \%$ \\
\hline $5-8 \mathrm{~m}$ & 6.5 & $18-20$ & $59 \%$ & $40 \%$ & $70 \%$ & $25 \%$ & 0.4 & $43 \%$ & $30 \%$ & $75 \%$ & 2.5 & $39 \%$ \\
\hline
\end{tabular}

In Table 2, the results of various analyses and the chemical composition of the waste fraction are shown, also here divided into the fractions from the upper part $(0-5 \mathrm{~m})$ and the lower part $(5-8 \mathrm{~m})$. There is a very clear division of the waste into a coarse fraction with most of the organics, and a fine fraction containing the inorganic mater (a soil fraction). For organic material, the nitrogen content is mostly present in the coarse fraction, while most phosphorus is found in the fine fraction (primarily shown in the samples from the lower level). 
Table 2. Total solids, ash content, low calorific value and concentration of different constituents in the waste at 0-5 and 5-8 $\mathrm{m}$ below the surface.

\begin{tabular}{|c|c|c|c|c|c|}
\hline & UNTT & $\begin{array}{c}\text { COARSE } \\
\text { FRACTION } \\
0-5 \mathrm{~m}\end{array}$ & $\begin{array}{c}\text { FINE } \\
\text { FRACTION } \\
0-5 \mathrm{~m}\end{array}$ & $\begin{array}{c}\text { COARSE } \\
\text { FRACTION } \\
5.8 \mathrm{~m}\end{array}$ & $\begin{array}{c}\text { FINE } \\
\text { FRACTION } \\
\mathbf{5 - 8 ~} \mathrm{m}\end{array}$ \\
\hline Total Solids & TS (\%) & 62.0 & 70.0 & 56.6 & 61.0 \\
\hline Ash content & $\%$ of TS & 39.3 & 78.9 & 36.6 & 84.0 \\
\hline Calorific value & $\mathrm{MJ} / \mathrm{kg}$ sample & 6.9 & $<2$ & 7.9 & $<2$ \\
\hline Carbon (C) & $\%$ by weight TS* & 32 & 13 & 44 & 11 \\
\hline Nitrogen $(\mathrm{N})$ & $\%$ by weight TS* & 0.74 & 0.45 & 0.49 & 0.57 \\
\hline Sulphur (S) & $\%$ by weight TS* & 0.39 & 0.71 & 0.27 & 0.56 \\
\hline $\begin{array}{l}\text { Phosphorus } \\
\mathrm{P} \text { (tot) }\end{array}$ & $\mathrm{g} / \mathrm{kg} \mathrm{TS*}$ & 0.77 & 0.72 & 0.66 & 1.5 \\
\hline $\mathrm{COD}_{\mathrm{O}}$ & g/kg TS* & 720 & 250 & 620 & 270 \\
\hline Magnesium (Mg) & $\mathrm{g} / \mathrm{kg}$ TS** & 0.84 & 1.6 & 0.99 & 1.6 \\
\hline Calcium (Ca) & $\mathrm{g} / \mathrm{kg}$ TS** & 12 & 17 & 7.6 & 15 \\
\hline Potassium (K) & $\mathrm{g} / \mathrm{kg}$ TS** & 1.4 & 0.99 & 0.85 & 1.3 \\
\hline Zinc $(\mathrm{Zn})$ & $\mathrm{g} / \mathrm{kg}$ TS** & 1.9 & 0.50 & 0.33 & 0.58 \\
\hline Nickel (Ni) & $\mathrm{mg} / \mathrm{kg} \mathrm{TS} * *$ & 6.7 & 12 & 8.7 & 30 \\
\hline Copper $(\mathrm{Cu})$ & $\mathrm{mg} / \mathrm{kg} \mathrm{TS}^{* *}$ & 90 & 53 & 41 & 140 \\
\hline Chromium $(\mathrm{Cr})$ & $\mathrm{mg} / \mathrm{kg} \mathrm{TS} * *$ & 39 & 36 & 8.1 & 39 \\
\hline Lead $(\mathrm{Pb})$ & $\mathrm{mg} / \mathrm{kg}$ TS** & 88 & 160 & 18 & 100 \\
\hline Cadmium (Cd) & $\mathrm{mg} / \mathrm{kg} \mathrm{TS}^{* *}$ & 7.1 & 1.6 & 0.57 & 3.4 \\
\hline
\end{tabular}

TS=Toul Solids

* Calculated based on the whole sample

** Calcubted based on the whole sample, but for the fractions metals glass, stone, sheetmetal, etc.

Leachate was observed to pour out from the wall of the excavated waste pit. The percolate was collected after $0 \mathrm{~h}, 1.5 \mathrm{~h}, 20 \mathrm{~h}$ and $121 \mathrm{~h}$ in order to investigate how the composition varied with time (Tables 3 and 4). 
Table 3. Main constituents in the leachate $(\mathrm{mg} / \mathrm{l})$.

\begin{tabular}{|l|c|c|c|c|c|c|}
\hline SAMPLE & $\mathbf{1}$ & $\mathbf{2}$ & $\mathbf{4}$ & $\mathbf{8}$ & $\mathbf{9}$ & $\mathbf{1 0}$ \\
\hline \hline $\mathrm{pH}$ & 8.2 & 7.9 & 7.7 & 8.5 & 8.6 & 7.9 \\
\hline $\mathrm{Cond} .(\mathrm{mS} / \mathrm{m})$ & 348 & 205 & 788 & 1048 & 972 & 1080 \\
\hline $\mathrm{Cl}$ & 270 & 135 & 585 & 800 & 730 & 780 \\
\hline $\mathrm{SO}_{4}{ }^{2-}$ & & 196 & 139 & 88 & 88 & 93 \\
\hline $\mathrm{P}_{\mathbf{b i}}$ & 1.4 & 0.7 & 4.5 & 8.1 & 7.4 & 8.1 \\
\hline $\mathrm{PO}_{4}-\mathrm{P}$ & 0.7 & 0.6 & 4.5 & 7.0 & 5.9 & 6.7 \\
\hline $\mathrm{Kj}^{-} \mathrm{N}$ & 252 & 122 & 616 & 798 & 728 & 798 \\
\hline $\mathrm{NH}_{4}-\mathrm{N}$ & 252 & 112 & 602 & 785 & 700 & 798 \\
\hline $\mathrm{NO}_{\mathbf{x}}-\mathrm{N}$ & 4.0 & 4.2 & 3.4 & 5.9 & 5.4 & 5.4 \\
\hline $\mathrm{BOD}$ & 60 & 173 & 80 & 85 & 55 & 70 \\
\hline $\mathrm{COD}$ & 635 & 510 & 675 & 1055 & 1025 & 1065 \\
\hline Susp. Solids & 2195 & 1132 & 582 & 652 & 634 & 382 \\
\hline Total Solids & 3552 & 2180 & 3472 & 5384 & 5072 & 5294 \\
\hline Fixed Solids & 2782 & 1620 & 2616 & 4304 & 4154 & 4194 \\
\hline FFA \% & 0.60 & 0.35 & 1.54 & 1.89 & 1.68 & 2.13 \\
\hline Fat & - & - & 4.5 & 81.5 & $<1$ & $<1$ \\
\hline
\end{tabular}
1) Pouring water $(-2 \mathrm{~m})$
8) Considerable seepage $(-5 \mathrm{~m},+20 \mathrm{~h})$
2) Pouring water $(-3 \mathrm{~m})$
9) Considerable seepage $(-5 \mathrm{~m},+1.5 \mathrm{~h})$
4) Considerable seepage $(-5 \mathrm{~m},+0 \mathrm{~h})$
10) Large seepage $(-5 \mathrm{~m},+121 \mathrm{~h})$

Leachate composition usually varies between different landfills; being dependent on the composition of the waste, the age of the landfill, the seasonal inflow of water to the landfill and, the transport path of the water to the sampling site. The degradation of the waste progresses through different phases, the initial acidic phase and the ensuing methanogenic phase dominating.

According to the characterization by Spinosa et al. (1991) of leachate during the different phases, the landfill mining area in Filborna was defined to be in the methanogenic phase. This is based on the $\mathrm{pH}$ values between 7.7 and 8.6, low $\mathrm{BOD} 5 / \mathrm{COD}$ ratio and a rather high level of $\mathrm{NO}_{4}-\mathrm{N}$. By comparing our values with those of Ehrig (1991) it was found that they were in agreement with the averages for the methanogenic phase. The concentrations of most of the constituents in the shaft seepage are almost constant during the 121-hour period investigated, except for the initial analysis.

According to Ehrig (1991), a ratio of BOD5/COD higher than 0.4 during the acidic phase indicates good biodegradability. During the methanogenic phase, the ratio decreases below $0 . \&$, indicating low biodegradability of organics. In our study, the BOD7/COD ratio was found to vary between 0.05 and 0.82 in all but one case, when the value reached 0.34 . 
Table 4. Concentration of metals in the leachate $\left(p p m,\left(^{*}\right)=p p b\right)$.

\begin{tabular}{|l|c|c|c|c|c|c|}
\hline SAMPLE & $\mathbf{1}$ & $\mathbf{2}$ & $\mathbf{4}$ & $\mathbf{8}$ & $\mathbf{9}$ & $\mathbf{1 0}$ \\
\hline $\mathrm{Al}$ & 0.254 & 3.305 & 0.438 & 0.176 & 0.153 & 0.158 \\
\hline $\mathrm{Ca}$ & 238.584 & 325.137 & 222.822 & 202.471 & 202.449 & 175.26 \\
\hline $\mathrm{Cd}$ & 0.003 & 0.002 & $<0.001$ & $<0.001$ & $<0.001$ & $<0.001$ \\
\hline $\mathrm{Co}$ & $<0.020$ & $<0.020$ & $<0.020$ & 0.022 & $<0.020$ & $<0.020$ \\
\hline $\mathrm{Cr}$ & $<0.007$ & 0.029 & 0.068 & 0.132 & 0.134 & 0.117 \\
\hline $\mathrm{Cu}$ & 0.034 & 0.052 & 0.021 & 0.043 & 0.029 & 0.022 \\
\hline $\mathrm{Fe}$ & 70.23 & 62.44 & 5.93 & 9.93 & 11.89 & 7.57 \\
\hline $\mathrm{K}$ & 181.385 & 82.133 & 297.289 & 418.872 & 386.641 & 414.91 \\
\hline $\mathrm{Mg}$ & 55.688 & 40.324 & 84.882 & 103.995 & 99.361 & 104.82 \\
\hline $\mathrm{Mn}$ & 0.557 & 2.096 & 0.574 & 1.079 & 1.163 & 1.113 \\
\hline $\mathrm{Ni}$ & 0.029 & 0.024 & 0.037 & 0.089 & 0.053 & 0.074 \\
\hline $\mathrm{Pb}$ & $<0.020$ & $<0.020$ & $<0.020$ & $<0.020$ & $<0.020$ & $<0.020$ \\
\hline $\mathrm{Zn}$ & 0.277 & 0.350 & 0.455 & 0.170 & 0.144 & 0.103 \\
\hline $\mathrm{Ba}$ & 0.040 & 0.236 & 0.516 & 0.672 & 0.577 & 0.750 \\
\hline $\mathrm{As}\left(^{*}\right)$ & 0.63 & 2.43 & 1.91 & 3.24 & 3.00 & 2.13 \\
\hline $\mathrm{Hg}\left(^{*}\right)$ & 1.07 & 1.41 & 0.52 & 0.64 & 0.79 & 1.04 \\
\hline $\mathrm{Na}$ & 235.07 & 146.34 & 555.33 & 1223.82 & 1077.51 & 1034.6 \\
\hline \hline $\mathrm{Po}$ & & & & & & \\
\hline
\end{tabular}

1) Pouring water $(-2 \mathrm{~m})$

2) Pouring water $(-3 \mathrm{~m})$

4) Considerable seepage $(-5 \mathrm{~m},+0 \mathrm{~h})$
8) Considerable seepage $(-5 \mathrm{~m},+20 \mathrm{~h})$

9) Considerable seepage $(-5 \mathrm{~m},+1.5 \mathrm{~h})$

10) Considerable seepage $(-5 \mathrm{~m},+121 \mathrm{~h})$

\section{Sampling}

A special sampling technique was developed. The waste layers in a vertical wall in the landfill were investigated. The wall was divided into squares of $1 \times 1 \mathrm{~m}$. The temperature was measured at 4 points in each square. A $0.7 \mathrm{~m}$ metal pipe ( $\mathrm{f}$ $150 \mathrm{~mm}$ ) was pushed into the centre of the square by the excavator in order to take waste samples. The pipe was dug out and the material (approx. 1-2 kg) in the pipe placed in plastic bags for analysis (see Photograph 4). The samples were analyzed for moisture, calorific value, ash content and concentration of different constituents. Random samples were taken from the screened fine fraction and sent to a laboratory for soil characterization.

\section{ENERGY FROM WASTE}

Excavation of mixed waste landfill in Sweden gave an energy value of 7-8 MJ/kg (Hogland et al., 1995). In studies in the USA an energy value of 5-6 MJ/kg (Salerni, 1995) was found and in Europe $11 \mathrm{MJ} / \mathrm{kg}$ (Obermeier and Saure, 1995) and $20 \mathrm{MJ} / \mathrm{kg}$ (Cossu et al., 1995). In our previous study (Hogland et al., 1995) the ash content was found to be $40 \%$ based on TS, the fine fraction had an energy value of $2 \mathrm{MJ} / \mathrm{kg}$ and the ash content was $80 \%$ (weight TS). However, it is 
difficult to quantify the total energy potential in the whole landfill as the degree of decomposition varies considerably in different parts of the landfill (Photograph 5). The excavated coarse fraction can usually be incinerated without the addition of fuel.

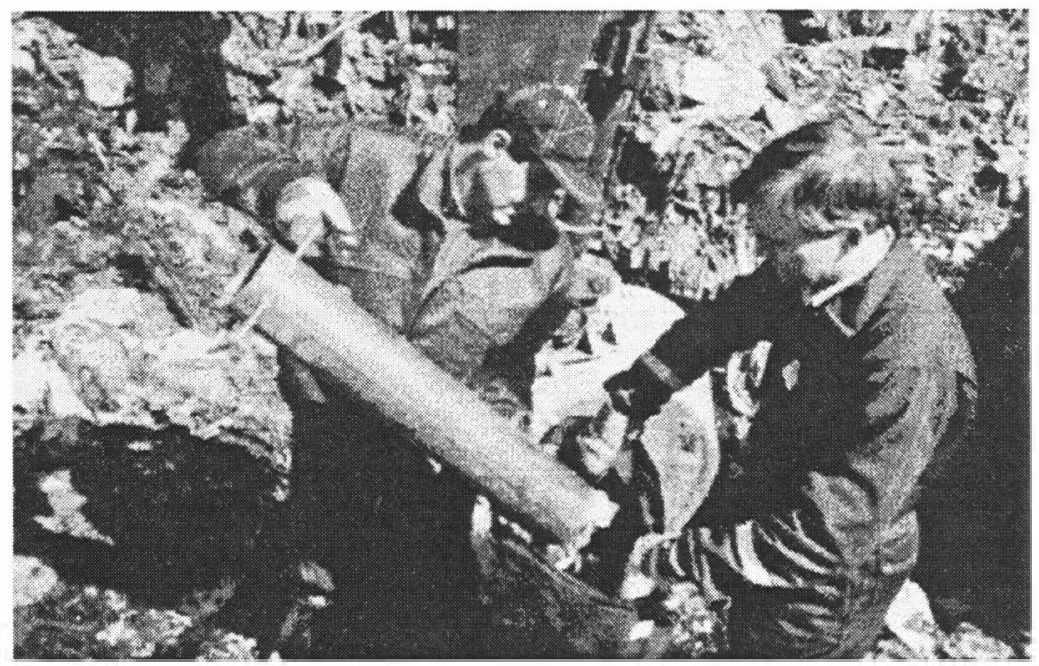

Photograph 4. Emptying of the sampling pipe.

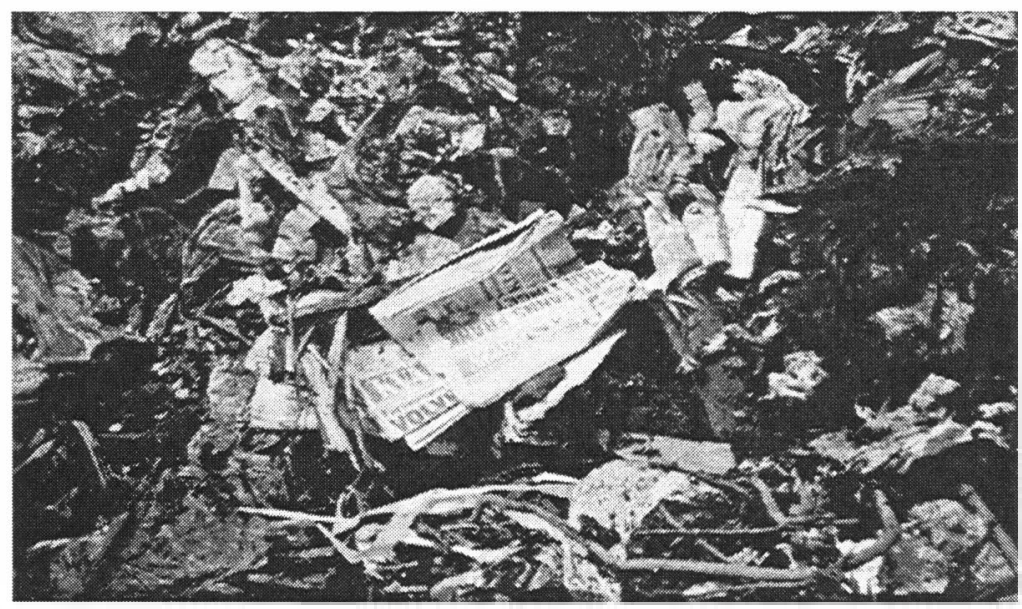

Photograph 5. More than 10-year-old newspapers found as new in dry zones in a MSW landfill in Sweden. 


\section{COVERAGE MATERIAL}

The fine fraction can be used as covering material. In some regions in Sweden, there is a lack of material for daily and final coverage. The quality of the screened fraction determines the use of the soil material. The first concerns are which standards should be used for the determination of the quality of the screened material. The simplest solution is to use standards, which are employed for the assessment of compost made from refuse. In Table 5, examples of standards from different countries (USA, UK, Germany, Canada, Poland and Denmark) are shown. (Standards do not yet exist in Sweden).

For most of the variables analysed, the concentrations are lower or in the upper range of what can be accepted for compost soil use in Germany and Canada. However, in some cases the $\mathrm{Cd}, \mathrm{Cu}$ and $\mathrm{Zn}$ values are slightly higher than those that are acceptable in Germany.

As results of the investigation of the finest material are obtained, the next step should be to consider what could be done to improve the quality of this fraction. The $\mathrm{C} / \mathrm{N}$ ratio in the fine fraction from the upper level was 29 and in the fraction from the lower level 19. A C/N ratio of 20 is a suitable value in final compost.

Table 5. Standards for compost soils and fertilizers for agricultural use in different countries. ( $\mathrm{mg} / \mathrm{kg} d r y \mathrm{wt}$ )

\begin{tabular}{|c|c|c|c|c|c|c|}
\hline ELEMENT & $\begin{array}{c}\text { US EPA } \\
\text { (a) }\end{array}$ & $\begin{array}{l}\text { UK } \\
\text { (b) }\end{array}$ & $\begin{array}{l}\text { GER- } \\
\text { MANY } \\
\text { (c) }\end{array}$ & $\begin{array}{c}\text { CANADA } \\
\text { (d) }\end{array}$ & $\begin{array}{l}\text { POLAND } \\
\text { (e) }\end{array}$ & $\begin{array}{c}\text { DENMARK } \\
\text { (f) }\end{array}$ \\
\hline Arsenic (As) & 41 & & & 10 & & \\
\hline Cadmium (Cd) & 39 & $10(2)$ & 1.5 & 3 & 0.8 & 5 \\
\hline Chromium (Cr) & 1200 & & 100 & 50 & 20 & 300 \\
\hline Cobolt (Co) & & & & 25 & 4 & \\
\hline Copper (Cu) & 1500 & $400(50)$ & 100 & 60 & 50 & \\
\hline Lead (Po) & 300 & $250(100)$ & 150 & 150 & 120 & 350 \\
\hline Mercuy (Hg) & 17 & $2(1)$ & 1 & 0.15 & 0.8 & \\
\hline Molybdenum(Mo) & 18 & & & 2 & & \\
\hline Nickel(Ni) & 420 & $100(50)$ & 50 & 60 & 30 & 100 \\
\hline Selenium (Se) & 36 & & & 2 & & \\
\hline Zinc (Zn) & 2800 & $1000(150)$ & 400 & 500 & 400 & 1500 \\
\hline $\mathrm{PCB}$ & & & & & & 0.5 \\
\hline Plastics & & & & & & $\begin{array}{l}1 \% \text { dwtnon- } \\
\text { degadable }\end{array}$ \\
\hline
\end{tabular}

a) Metal limits proposed for sewage-sludge-based composs by the US EPA under Part 503 of the Clean Water Act. The US EPA publisted a finalversion of these regulations in February 1993, but has allowed for additional public comment; therefore, the above values are not generally applicable. 
b) UK Soil Associntion Standards for maximum permissible levels of metals in compos and fertilize r used in organic farming. Manure and fertilzers ( ) = seed, potting, blocking, and mushrom compos (Dorau, 1992; Bardous, 1992).

c) Voluntary he avymetal standards for composts to bear the German AL Label (Briton, 1992).

d) Quality requirements for compos producs used in an unresticted mannerin Ontari, Canada (Gies, 1992).

e) Polish standards BN-89/9103-09.

Danishstandards (Danish Enviranmental Protection Agency 24.02.88, Danish Enviranmental Ministry Act no.736 of 26 Sept. 1989).

\section{FURTHER RESEARCH}

The necessitity of machinery development and excavation techniques has been well documented in the USA. However, the following are still required:

- further information about post-conventional closure costs,

- composting techniques for the reduction of the organic content of separated refuse,

- better methods and equipment for dealing with rocks,

- techniques for odour control during excavation and screening,

- processing methods and equipment for separation of plastic as well as for construction and demolition waste,

- methods for the separation and treatment of wet waste and soil and,

- improvement in the quality of the separated waste and the possibilities for further use.

Further research and investigations are needed on:

- to air and water emissions during excavation,

- a methodology for feasibility studies,

- sampling techniques and the collection of representative samples,

- the development of analysis methods,

- material characteristics as a function of the age of the waste and other factors,

- physical, chemical and biological processes in the waste,

- degradation and variations in time and space,

- coverage methods,

- energy aspects,

- economic aspects and

- environmental and working environment risks.

There is also a need for excavation guidelines and standards for the use of recyclable materials. 
From the environmental protection point of view is important to decide whether it is better to excavate an old landfill, possibly causing high emissions for a short period of time, or leave it intact and accept lower emissions over a longer period of time. Another important question is whether the economic incentive for landfill mining is sufficiently large, and fits in with the ideas of an eco-cyclic society, with both energy and material recovery.

\section{ACKNOWLEDGEMENT}

Thanks are directed to: The Swedish National Board for Industrial and Technical Development (NUTEK) and The Swedish Institute (SI), FRN for giving us financial support for our projects in Sweden; the Southwest Scania Waste Management Company AB (SYSAV AB) who supplied us with data and information and gave us access to the landfill for research studies. We also want to thank the Waste Management Company NSR, professor Cossu, University of Cagliari, Italy, Dr E. Salemi, USA and Dr K. Jagodzinski, Poland for valuable information and support in the project.

This paper has also been presented at 2nd International Symposium on Waste Disposal, June 18-20, Salvador, Bahia and therefore we also want to thank CONDER, ABES and Governo do Estado da Bahia in Brazil for inviting us to participate in that Symposium, as well as Rio de Janeiro State University - UERJ, Brazil.

\section{REFERENCES}

Bilitewski, B.; Conrad, H. and Grischek, H. (1995). Transposition and reconstruction of old landfill sites in East Germany. Proceedings Sardinia 95 - 5th International Landfill Symposium, Cagliari, Italy, 2-6 October 1995, Volume III, pp 807-818.

BIOSAFE (1995). The Landfill Remodelling Company. BioSafe, 10 Fawcett Street, Cambridge, 1995.

Brammer, Frammer, F., Kucklick, M.; Collins, H. J.; Hanert, H. (1995). Landfill mining: a possibility to reduce landfill volume and environmental pollution. Proceedings Sardinia 95 - 5th International Landfill Symposium, Cagliari, October 2-6 1995, Vol. III, pp 795-806.

Calrecovery Inc. (1993). Solid Waste Association of North America (SWANA) Evaluation of Collier County, Florida Landfill Mining Demonstration. Prepared for U.S. EPA, Contract No 850-09991-1, EPA/600/R-93/163, Cincinnati, Ohio, USA, September 1993.

Cossu, R.; Motzo, G. M. and Laudadio, M. (1995). Preliminary study for a landfill mining project in Sardinia. Proceedings Sardinia 95 - 5th International Landfill Symposium, Cagliari, Italy, 2-6 October 1995, volume III, pp 841-850. 
Flosdorf, H. (1993). Landfill Reclamation-is this the Ultimate form of Recycling? Warmer Bulletin, No 38, August 1993.

Flosdorf, H. W. and Alexieff, S. (1993). Mining landfills for space and fuel. Solid Waste and Power, March/April, 1993, Vol. VII/No 2: 26-32.

Friedmann, H. and Zollner, F. (1995). Behandlung und Verwertung von Altmüll aus dem Deponierückbau. Abfallwirtschaft Journal, 1/2, 1995, pp 76-81. (in German).

Fry, F. F. (1995). Reclamation plant for an unlined landfill in the York County, USA. Proceedings Sardinia 95 - 5th International Landfill Symposium, Cagliari, Italy, 2-6 October 1995, volume III, pp 851-856.

Hogland, W. Jagodzinski, K. and Meijer, J. E. (1995). Landfill mining tests in Sweden. Proceedings Sardinia 95 - 5th International Landfill Symposium, Cagliari, Italy, 2-6 October 1995, volume III, pp 783-794.

Laudadio, M. (1995). Ricercae sperimentale sul post-trattamento dei rifiuti depositati in discarcia. Master Thesis, University of Cagliari, Department of Geoengineering and Environmental Technologies, University of Cagliari, Italy. (in Italian).

Mangialardi, V. (1995). Reclaim Canada R. Cave and Associates, Reclaim 95 3rd Annual Conference, Landfill Mining, 1995.

Nelson, H. (1994). Landfill reclamation strategies. BioCycle, October, 1994, pp 40-44.

Nelson, H. (1995). Space and materials recovery- Landfill reclamation projects on the rise. BioCycle, March 1995, pp 83-84.

Obermeier, T. and Saure, T. (1995). Landfill reconstruction, biological treatment of landfill waste. Proceedings Sardinia 95 - 5th International Landfill Symposium, Cagliari, Italy, 2-6 October 1995, volume III, pp 819-826.

PBSJ. (1992). Feasibility Study Excavation \& Recycling of Area 'A' for Delaware Solid Waste Authority Dover, Delaware Post, Buckley, Shuh \& Jemigan INC., Winter Park Plaza, Florida, 1992. 109 pages.

Rettenberger, G. and Göschl, R. (1994). Ergebnisse und Betrieberfahrungen aus dem Demonstrationsprojekt "Deponierückbau Burghof". Deponierückbau Seminar 8 November Stuttgart Germany (in German).

Rettenberger, G. (1995). Results from a landfill mining demonstration project, Proceedings Sardinia 95 - 5th International Landfill Symposium, Cagliari, Italy, 2-6 October 1995, volume III, pp 827-840.

Salerni, E. (1992). Town of Edinburg landfill reclamation demonstration project. Prepared for the New York State Energy Research and Development Authority, May 12 1992, Report 92-4. 148 pages.

Salerni, E (1995). Landfill Reclamation Manual. Reclaim-95 Landfill mining Conference, September 28-29, 1995.15 pages. 
Savage, G. M.; Golueke, C G and Stein, E L. (1993). Landfill Mining: Past and Present. BioCycle, May, 1993.

Savage, G. M. and Diaz, L F. (1994). CalRecovery, Inc.,USA. Landfill Mining and Reclamation. ISWA Times No 4, 1994, pp 1-4.

Saure, T. (1993). Grundlagen und Untersuchungen zur aerob-biologishen Behandlung von Altmüllfraktionen im Rahmen einer Deponierekonstruktion. Diplomarbeit am Institut für Technischen Umweltschutz der TU Berlin,Berlin 1993, pp 479-483. (in German).

Schillinger, et al. (1994). Summary of Landfill Reclamation Feasibility Studies. NYSERDA, 1994. 165 pages.

Spencer, R. (1991). Mining landfills for recyclables. BioCycle, February1991, 34-36.

TWRF (1995). The World Resource Foundation, Landfill mining. TWRF, Bridge House, High Street, Tonbridge, Kent, 1995.

Visalli, J.; Reis, J.; Morelli, J. and Frank, M. J. (1992). Town of Edinburg Landfill Reclamation Demonstration Project. New York State Energy Research and Development Authority, 1992. 